\title{
Thinking about God today: Eavesdropping on four discourses
}

\begin{abstract}
The article investigates the contemporary academic reflection on God and addresses the question as to whether there are new perspectives and sensibilities which destabilise the persistent classical theistic notion and prompt alternative constructions. A concern for speaking of God in a responsible and contextual manner forms the background of the study. Four major contemporary discourses, which have issued significant new challenges to the tradition doctrine of God, are identified and explored: those in Biblical Studies, Trinitarian Renaissance, Alterity Studies, and Philosophy of Religion. The article raises the question of an episteme of theorhetoric which structurally addresses the constituent elements of a 'doctrine of God' and intimates that the present moment may be evidencing a new trajectory in the genealogy of God.
\end{abstract}

\section{INTRODUCTION}

Those who dare to think about God, those who are brave to bring this elusive mystery to speech, are confronted with the challenge: How do we do this? Is there a grammar to Christian utterance about the divine? What contemporary sensibilities constrain our speaking? What is the present state of academic reflection that may guide us? This is the focus of this article: the horizon for raising and expressing the question of God at this moment in time.

The background and rationale for theorising this include not only the continuous public interest in this reality, but also the imperative for theology to account for her central task. Arguably, reflection and speech about the Ultimate, the Transcendent, is the core activity of theology. A further reason can be added to these motivations for addressing the question about conditions for speaking: the widespread dissatisfaction with classical theism, ${ }^{2}$ and the proliferation of alternative proposals. In short, are there significant developments which one should take note of when speaking about God?

This article is submitted to a volume honouring Professor Vincent Brümmer for a long career of intellectual activity which has been addressing ultimate questions. The prominence of God and, specifically, the emphasis on the personal nature of God, on love and later even on the trinity in his oeuvre remain a constant inspiration to others. His work motivated a generation of younger scholars to think more deeply about the nature of God. ${ }^{3}$ This article intends to contribute in a modest way to that similar goal of probing deeper into the mystery of God, and

1 Department of Systematic Theology, Faculty of Theology, University of the Free State, Bloemfontein. E-mail: rianventer@mweb.co.za.

2 Numerous concerns have been raised about classical theism: for instance, it tends to closure; it is oblivious to diverse human experiences, especially of suffering; it is based on a dated metaphysics; it ignores its own potential ethical impacts, and there is a tension between the confession of the trinity and the exposition of the divine attributes.

3 In this regard, see the explicit comment by Prof Brümmer in his autobiographical sketch (2006:20). 
as such wants to recognise the seminal influence of Professor Brümmer.

The notion of 'discourse' will be central in my approach, as it seems to me that the primary access in the academy to God is mediated by expressions of experience, by articulations of reflection and by eventual tradition formation. By doing this, the danger of a claim to unmediated access is avoided. Standing in my study in front of the bookcase with the collection of books on God, I get a number of impressions. There is not only a steady stream of new publications, but it is not too difficult to group the various works in categories. There is undeniably an enthusiastic interest in the God question, ${ }^{4}$ but it takes place along disciplinary lines or at least in academic communities with similar interests, presuppositions and methodologies. In the next section, I will mention the outstanding discourses and then describe the main features of only four, which I consider crucial for Christian theology.

Needless to say, my intention with the article is consciously modest. My contribution is at most an intimation of how this problem could be approached, at least by mentioning discourses which are not usually mentioned in the same space. Thinking about God in the present requires that one should overhear the various discourses which are taking place.

\section{EAVESDROPPING ON DISCOURSES}

The impression is often of a lack of intentional border-crossing or inter-discursive exploration. At least eleven discourses on God can be identified, and the following may form the most prominent: those on New Atheism, cognitive science of religion, ${ }^{5}$ Biblical Studies, ${ }^{6}$ Trinitarian Renaissance, alterity, ${ }^{7}$ faith-science, ${ }^{8}$ global Christianity, ${ }^{9}$ inter-religious dialogue, ${ }^{10}$ spirituality and mysticism, ${ }^{11}$ postmodern philosophy of religion, and traditional systematic theology. ${ }^{12}$ In this short article, attention will be paid to four of these discourses, namely Biblical Studies, Trinitarian Renaissance, alterity and postmodern philosophy of religion, which I deem particularly important for Christian Systematic Theology, and which may give an indication of possible new avenues for thinking about God. Although treatment will be fairly introductory, care will be taken to note some of the most important literature available in each discourse to enable, it is hoped, more detailed exploration.

\subsection{Biblical Studies}

Developments in the field of Old and New Testament studies are, for obvious reasons, important for theology in general. It would be more accurate to refer to discourses in the plural to convey the diverse approaches within Biblical Studies, especially in Old Testament. My impression is

4 Tracy (1994a) speaks about the "return of God in contemporary theology".

5 See Tremlin (2006).

6 This is diverse and will be discussed in section 2.1

7 This covers a wide range of reflection, including Feminist, Black, Liberation, and Postcolonial Studies.

8 This can refer to several interests. The discussion on panentheism is particularly noteworthy and prominent. See Clayton \& Peacocke (2004).

9 The textbook by Kärkkäinen (2004) gives a clear introductory overview of, for example, those in Africa and Asia.

10 For some excellent essays, see Jeanrond \& Lande (2005). See also the volume on Naming and thinking God in Europe today (Hintersteiner 2007) which has excellent articles on God, giving not only various geographic reflections, but also global and inter-religious conversations.

11 For one insightful treatment from a Trinitarian perspective, see Hunt (2010).

12 This indication is awkward and not particularly satisfying. In this instance, I have in mind some earlier discussions on eschatology and God, and more recent controversies on Open Theism in Evangelical circles. For introductory discussions of the main developments, see Callen (2004). 
that methodology could be a key avenue to gauge advances. The method selected for studying determines the field of focus, the set of questions and, finally, the kind of answers that could be expected. Method is an expression of deeper convictions of what the Bible is or what a specific testament signifies. A simple comparison of well-known works, such as Brueggemann's Theology or Albertz's History of Israelite religion, illustrates this well. If one adds the more recent work by Feldmeier and Spieckermann - God of the living - the problem becomes even clearer. The question of history vs. theology, ${ }^{13}$ and of the extent of intra-canonical unity and plurality form the basic divide in this set of discourses. Overhearing the conversation, I can identify at least five potential contributions in Old Testament Studies to the overall reflection on God.

The History of Religion approach with all its sophistication and attention to detail aspects ${ }^{14}$ has reinforced one overall impression: the evolving nature of Israel's conceptualisation of the divine resulting from interaction with changing social conditions. No single profile of the divine can be 'paused' in time, as if it can be sanitised from interaction with a social world riddled with conflict. When the word 'god' is uttered, a genealogical antenna is activated. The rise of monotheism is a prominent case in point.

More recent theologies - especially those by Brueggemann (1997) and Gerstenberger (2002) - give expression to this internal plurality, whether with the notion of tradition and countertradition or with theologies. These scholars persuasively argue and demonstrate that the Old Testament, as collection of literature reflecting diverging traditions with even conflicting construals of reality, presents complex portrayals of the divine. An a-historical deity, whose nature could be distilled and mastered in single adjectives such as 'holy', 'almighty', is something of the past.

The employment of narratological interpretative strategies has strengthened the case for the "kaleidoscopic nature of divine personality" (see Noll 2001): God appears now as a character with a complex nature in specific books ${ }^{15}$ and specific traditions.

It is striking how many voices have - increasingly - raised concern about the problematic nature of some of the divine images. Once the stranglehold of a generic portrayal has been released, the peculiar behaviour of the divine has started to crystallise. This dark side of Israel's deity is one of the typical features of her history. ${ }^{16}$

A number of scholars, such as Schwartz (1997) and Assmann (2010), have investigated the performative effect of the rise of monotheism. Exclusion, violence and monotheism are disturbingly related. The particular importance of these studies underlines the radical social significance of God-images; they are never innocent. The inherent ethical dimension of the human understanding of God deserves careful attention.

Turning to the New Testament, one encounters similar methodological intuitions. Several recent studies have redressed the lament of Dahl (1991) that God is a "neglected factor in New Testament theology". Not only has the God representation of various New Testament traditions been studied in depth, ${ }^{17}$ but new methodological explorations have also been suggested. The detailed and innovative study by Neyrey (2004), who advocates a social-scientific approach, should be mentioned. ${ }^{18}$ In his important recent study, Hurtado (2010:111f) argues strongly that

13 For an instructive treatment, see Lemche (2008).

14 For example, the origin of Yahwism, the emergence of monotheism, the Asherah tradition, and aniconism. The preface to Smith's revised work (2002) is exceptionally instructive.

15 For a narrative reading of God in the Book of Genesis, see Humphreys (2001), for one example.

16 The literature on this is growing. Siebert (2009) gives a detailed discussion of the various problematic texts and possible interpretative strategies.

17 For example, the Gospel of John has been a particular favourite for such investigation. See, for instance, the work by Thompson (2001).

18 The fruitfulness of this approach has, to my knowledge, not been sufficiently appreciated. For example, 
the New Testament "express(es) a major reconfiguring of God-discourse". He also refers to a "major innovation" encountered in the NT. ${ }^{19}$

\subsection{Trinitarian Renaissance}

The re-appreciation of the Trinitarian confession is one of the outstanding theological developments of our time. For some, like Grenz (2004:6), it could be even the greatest contribution of theology in the twentieth century. Three recent publications map the renewed interest in the trinity well, ${ }^{20}$ giving a comprehensive overview of the many dimensions to this discourse. The significance of this so-called Trinitarian Renaissance is wide-ranging. It has not only re-opened established theological positions, such as the assumed difference between the East and the West, and the alleged one-sided influence of Augustine, but also encouraged consistent Trinitarian interpretations of the Christian dogmatic and social visions. ${ }^{21}$ Typical of discourse, this one likewise offers unanimous positions, and on certain crucial aspects allows the ways to part. It may be safe to refer to minimalists and maximalists, to distinguish between those who limit the meaning of the confession to Christology, and those who employ the confession as a regulative framework for doing theology as such.

For the focus of this article, it may be productive to enquire after the "point of Trinitarian theology" to use Jenson's (1995) apt phrase. In the biblical narrative, the life of God is revealed to humanity, and this life is relational. Arguably, more than before, the identity of God in the Christian tradition, is conceptualised in terms of relationality. The roots to this conviction may be found in the philosophical "turn to relationality", 22 or in postmodern sensibilities. ${ }^{23}$ Whatever the stimuli, the point of the new appreciation is to be found in this instance: ultimate reality is not monistic, but relational. The significance of this relational turn should not be devalued. One could argue for a third trajectory in theistic thinking: the first being the formulation of inclusive monotheism, the second substantial trinitarianism, and now a third mutation - thinking along different categorical and metaphysical lines.

The disruptive effect of Trinitarian thinking on generic notions of the divine may be the critical significance of this discourse. It destabilises ingrained and ossified understandings of what is referred to when one utters the word 'god'. Rethinking the attribute tradition may be one of the important consequences of this discourse. ${ }^{24}$ Interestingly, consistent Trinitarian thinkers have realised that divine perfections should be re-envisioned. For instance, Barth in surprising moves has highlighted "space" and "beauty" in his systematic treatment of God. ${ }^{25}$ The Trinitarian turn opens avenues for truly creative and contextual construals, which may be

he discusses the construal of God in Romans in light of Greco-Roman philosophy which structures the doctrine of God according to epistemology, physics and ethics. The indebtedness of the NT to the Judean and Greco-Roman world is stressed by Neyrey. For instance, the nature of true deity in Hebrews (see 7:3) draws heavily on Greek philosophy - Jesus is a divine figure, because he fulfils the typical requirement with his eternity (see 2004:241f).

19 The major factor in the NT, according to Hurtado, is the inclusion of Jesus as a distinguishable figure along with God in early Christian devotion.

20 See esppecially Emery \& Levering (2011) - The Oxford handbook to the Trinity; Phan (2011) - The Cambridge companion to the Trinity, and Woźniak \& Maspero (2012) - Rethinking Trinitarian theology.

These volumes represent the most recent state of scholarship and give excellent overviews of this multifaceted discourse.

21 For an excellent and concise discussion, see Kärkkäinen (2009).

22 See Shults (2005:5-9).

23 See the excellent treatment by Cunningham (2003).

24 Gunton (2002) discusses this at length. Krötke (2001) is an outstanding treatment of the attribute tradition.

25 See Barth (1957:461-490, 640-677.) 
legitimate extrapolations of traditional positions and hermeneutically responsible speaking to new conditions. For example, the notions of 'hospitality' ${ }^{26}$ or 'vulnerability'27 belong logically to the tradition of God as relational, and suggest constructive possibilities for speaking about God in our time.

Trinitarian thinking not only harbours a surplus of meaning for contextual speaking, but also heightens the very mystery and hiddenness of God. In the East, Trinitarian confession has been coupled with a strong impulse towards apophatism. It stimulates at once the imagination and motivates new speaking, but leads also to silence and adoration. The new interest in the mystics and their understanding of the divine should not escape notice. ${ }^{28}$

\subsection{Subaltern Voices}

Decentring and disrupting of intellectual perspective may be considered as one of the truly significant advances of academic endeavour of the twentieth century. The faces of the other, ${ }^{29}$ the subaltern voices so long suppressed, have acquired a privileged space and have transformed thinking irreversibly, also about the divine. A host of intellectual prophets have become iconic to convey the basic thrust at stake in this intellectual revolution - Levinas, Spivak, and Said.

The re-imagining of God, advocated by Black, Feminist and Liberation theologians, is widely known and need not be conveyed in this instance. Work such as McFague's Models of God and Johnsons's She who is have become theological classics. ${ }^{30}$ The central place accorded to experience and to the role of language and its performative effects distinguishes this discourse markedly from traditional and classical theism. The divine is not only named in new and creative ways, but is rethought in relation to historical suffering and justice. The typical image of the impassible God has been radically destabilised.

The critical contribution of much of this work of the past forty years is to be found, in my opinion, in the epistemological rupture manifested in the God construals. ${ }^{31}$ Classical theism was based on an implicit a-historical framework, immunised from larger social conflicts and, in most cases, legitimising these very social configurations. The innocent image of God, resulting from a seamless move from Bible to dogmatic proposition, has been shattered. Not only does the Bible represent the divine in complex and pluriform ways, but the very act of representation is also fraught with gender, racial, and economic interests and concerns. The epistemological transformation of the traditional doctrine of God inevitably raises questions about whose knowledge, and knowledge to what effect? The re-imagining of God cannot avoid the pervasiveness of power and corresponding social visions.

Apart from this central tenet about the epistemic, another fundamental perspective emerges. Not only has the naming of God from new experiences and with alternative language been placed on the theological agenda, but also the question about God and alterity as such. To what extent do our images resist otherness, and to what extent do they enable us to negotiate

26 For an ambitious discussion, see Newlands \& Smith (2010).

27 For a general treatment of vulnerability, see Culp (2010). The work could have been much more emphatic on God's vulnerability, and not focus so exclusively on human vulnerability.

28 See Hunt (2010).

29 The overlap between this discourse and the postmodern elements of the next should not be missed. For an incisive discussion of "the real face of postmodernity ... is the face of the other", See Tracy (1994b). Henriksen (2010) gives a good treatment of the link between postmodern thinking and developments in philosophy of religion, especially with reference to Westphal and Caputo.

30 The recent work by Johnson Quest of the living God (2008) gives an excellent overview of the various approaches in this broad discourse - the "Liberating God of Life", the "God acting womanish", the "God who breaks chains", and the "Accompanying God of Fiesta".

31 For an excellent discussion of this, see the article by Frostin (1985). 
and embrace it? At stake in this case is the crucial interplay between notions of the divine, selfconstruction and social vision. For example, notions of holiness could result in self-understanding of uniqueness with terrifyingly violent social programmes. The overlap between this discourse and the previous one on the Trinity should not be overlooked. Social trinitarianism is attractive for this reason: it does not only locate otherness in the eternal life of God, but also furthers a corresponding notion of identity in terms of relationality. ${ }^{32}$ Authentic selfhood is construed in terms of mutuality and self-donation. No direct line is suggested in this instance between an understanding of God and a specific social programme. The danger of this has been pointed out too many times, especially in critiques of social trinitarianism. However, the causal link between notions of transcendence, the divine, God, self and society cannot be easily dismissed, irrespective of how complex this interplay may be. When contextual theology is pursued, also in a country such as South Africa, with social and relational pathologies, the question of God and alterity should be addressed.

\subsection{Postmodernism and Philosophy of Religion}

The so-called 'turn to religion' is one of the fascinating developments of the late twentieth century, especially by philosophers who are not known for their particular religious affinity. This complex phenomenon cannot be treated in this article; suffice it to state that there are various trajectories to this, and the intellectual interest is motivated by different interests, some by social-ethical and others by more metaphysical considerations. In this instance, I am interested in one specific sub-discourse - the postmodernist, one which is emphatically responsive to Heidegger's notion and critique of onto-theology. This includes conversations by scholars such as Marion, Caputo, and Kearney, and one which has generated a set of terminology which, I believe, could be fruitful for thinking about the divine. The problem, which Heidegger identified, is the long tradition which determines in advance by way of a specific metaphysic how God will enter thinking. God is the end of a long chain of being, the Supreme Being, the causa sui. Philosophy makes the rules which God will play. At stake in this case is the concern to honour alterity, to avoid reducing it to an object: "onto-theology involves the sacrifice of divine alterity" (Westphal 2004:16). ${ }^{33}$ Only radical Otherness allows for self-transcendence which, in turn, becomes a resource for self-transformation. If the Other is within my grasp and control, there could be no disruption of the self.

Jean-Luc Marion's book God without being has acquired the status of a classic as response to over-coming onto-theology. His work ${ }^{34}$ is an attempt to think God 'otherwise than being', in excess of onto-theology. His phenomenological approach, which premises primacy of givenness, is an alternative to the tradition of metaphysics. Radical givenness is irreducible, unconditional and absolute, and prior to any form of category. Marion subsequently advanced the notion of the 'saturated phenomenon'. Kearney's project to think God after metaphysics is aptly described as anatheism: a return to God after the atheistic critique of the traditional God of onto-theology. ${ }^{35}$ For him, God is a self-surpassing possibility whose posse exceeds his esse. Kearney does not subordinate possibility to actuality as is done in classical metaphysics. 'Possibility' is not mere potency, but is eschatological. God should be thought as the one who is to come, in the form of

32 Volf (1998:408ff), in particular, has articulated this emphatically. He refers to the "Trinitarian construction of identity" (:420). Rieger (2008:145) voices a particular additional insight with reference to pneumatology: as self-effacing God, whose selfhood lies precisely in empowering others, the Spirit embodies a new way of being person.

33 Westphal attended in various publications to the problem and challenge of onto-theology. For an excellent discussion of Heidegger's notion, see 2004, chapter 1.

34 For an exceptional discussion of the philosophical structures of his thought, see James (2012:17-38).

35 See his work Anatheism (2010). 
promise. His work The God who may be is an imaginative proposal to think God not in terms of the actual, but in terms of the impossible. Caputo, who has been instrumental in leading a series of most important debates at Villanova University, especially between Marion and Derrida, has produced his own programmatic statement with The weakness of God. As alternatives to traditional notions of God, he emphasises God as event and as weak force. For him, God cannot be placed in a pre-established ontological framework. Events are uncontainable and associated with advent. God is anarchical and disturbing, and as weak force does not legitimate the forces of this world, and is not its stabilising centre, but rather the very subversion thereof.

The 'impossible' has emerged as a key common category to convey these postmodern intuitions and sensibilities. ${ }^{36}$ An outstanding theologian such as Tracy, who has been an active participant in this discourse, has embraced this as a promising manner to name God. This convey not only the resistance to fit God into a modernist horizon of intelligibility, but also God's hiddenness, incomprehensibility and excessive gifting. This interpretation integrates various theological streams: a re-appreciation of the apocalyptic and apathetic traditions and a radicalising of the love motif. 37

This discourse, with its quest for avoiding the pitfalls of traditional metaphysics and the insistence on employing alternative modes of thinking, is a fruitful attempt to move speaking of God forward. Not only does it encourage more sophisticated ways to thinking about transcendence, but with notions such as gift, excess, weakness, and the impossible it also strives to avoid idolatry, which has always been prominent in serious God-talk.

\section{CONCLUSION - WHISPERS OF A THEO-EPISTEME}

One may need a musical metaphor to account for the various sounds in some form of melody. Whether it would even be possible to talk of conventional harmony is questionable. Some qualifiers should also be explicitly stated. My concern is that of the Christian systematic theologian, and not that of a philosopher of religion, and I am aware that my overview was selective and fairly brief. What follows is a hesitant whisper of elements of a theo-episteme. ${ }^{38}$

1. The Christian imagination has never been without a sense of the complexity of speaking about God. Arguably, the twentieth century has heightened this and no responsible theologian will venture into an academic exposition without sophisticated self-reflexivity. Thinking and speaking about God requires an explicit awareness of one's underlying cosmology, metaphysics and its categories, methodology, philosophy of language, and epistemology. The shifts in the twentieth century intellectual horizon render a continuation of traditional God-talk untenable. For instance, the understanding of character in narrative, the status and function of metaphor, the implication of relationality, and the permeation of knowledge with power require a new form of discourse.

2. Creative portrayals are not an option, but an imperative in new social conditions. The awareness of the plurality of biblical traditions and genealogical shifts in the Judean-

36 See, for example, the work by Gutting (2011) which argues that French philosophy since the 1960s has been primarily concerned with thinking the impossible.

37 Tracy has stated his position in a large number of publications. For an outstanding summary of his understanding of the Impossible, see especially 2011:124-127.

38 A comprehensive episteme will arguably account for what the referent is, i.e. what reality is referred to; for epistemology, how do we know; for rhetoric, what language is employed; for metaphysics, what conceptuality is used; for a divine symbolics, what identify the unique divine perfections; for agency what is the divine-world relationship; for discursive functions - what role "God" plays in discourse, and for the particular social generative situation. 
Christian consciousness not only warrant, but also require new theo-imaginings. A refusal to name the divine mystery in each new social situation may amount to idolatry, because the inexhaustible riches of God are inhibited.

3. God's life has salvific power in each new situation. Naming God contextually should intentionally aim at performing divine liberation and healing linguistically. Identifying the divine reality has had historically decisive effects on human self-understanding. The performative quality of human speech makes all thinking and speaking about God expressly ethical. Speaking about God and new construals of God have a political task, for example, matters such as reconciliation, justice and embrace of the other should be considered.

4. The Trinitarian identification of God has been disruptive of generic speech about the divine. The enduring contribution of this trajectory in the theo-genealogy is to keep the issue of the nature of the referent open. When we say 'god', what do we refer to?39 A mastery of this question, of closure of this fundamental human question will amount to ultimate hubris. The question of the nature of the referent is the question of the final mystery of life. The critique of onto-theology may always remind us of this. Human categories should always be tentative. Two hundred years from now, how will we refer to the Transcendent?

5. The function of 'God' in discourse requires careful consideration. 40 Reflection on this is usually neglected. God functions not only causatively as agent, but also mimetically to motivate by example. Discursively and rhetorically 'God' is used as warrant to reinforce legitimisation. Finally, there is a heuristic function: from a theo-centric perspective, God could serve as final explanation for issues such as origin, beauty, and so on. These functions can easily be discerned in discourse. With the growth of human knowledge and science, these may become increasingly problematic.

6. The hiddenness of God deserves renewed theological investigation, and recent interest in this is a productive development. The issue of the nature of the referent underlines the importance of this. Neglect of appreciation of the divine's ultimate mystery, excess and inexhaustibility usually and easily results in banal atheistic critique.

7. The suggestions to signify the nature of the divine in terms of relationality, love, gifting, event, and excess, in short - the impossible, may generate a grammar for a theosymbolics. Thinking and speaking about God, with such human words may reveal our own mystery and destiny. And our responsibility.

As final horizon of life, as ultimate mystery, God will never allow human reflection to come to rest. Recent discourses have heightened the sense not only of complexity and of the imperative of new and creative imaginings, but also of the ethical task of theology to perform God in language to enable reconciliation and justice. While doing this, the astonishment at God's hiddenness will remain the theologian's constant agony and joy.

\section{BIBLIOGRAPHY}

Albertz, R 1994. A history of Israelite religion in the Old Testament period. Vols 1 \& 2. Louisville:

Westminster John Knox.

Assmann, J 2010. The price of monotheism. Stanford: Stanford University Press.

Barth, K 1957. Church Dogmatics 2/1. The doctrine of God. Edinburgh: T \& T Clark. Brueggemann, W 1997. Theology of the Old Testament. Minneapolis: Fortress.

39 Wright (2009:444) explicitly raises the provocative question: "By the way, what is God?"

40 See my article (2010) for an exploration. 
Brümmer, V 2006. Brümmer on meaning and the Christian faith. Collected writings. Aldershot: Ashgate. Callen, B L 2004. Discerning the divine: God in Christian theology. Louisville: Westminster John Knox. Caputo, J D 2006. The weakness of God: A theology of the event. Bloomington: Indiana University Press. Clayton, P \& Peacocke, A (eds.) 2004. In whom we live and move and have our being: Panentheistic reflections on God's presence in a scientific world. Grand Rapids: Eerdmans.

Culp, K A 2010. Vulnerability and glory: A theological account. Louisville; John Knox Press.

Cunningham, D S. 2003. The Trinity, in Vanhoozer, K J (ed.), The Cambridge companion to postmodern theology, 186-202. Cambridge: Cambridge University Press.

Dahl, N S 1991. The neglected factor in New Testament theology, in Idem, Jesus the Christ (ed. by D H Juel), 153-163. Minneapolis: Fortress.

Emery, G \& Levering, M (eds.) 2011. The Oxford handbook to the Trinity. Oxford: Oxford University Press. Feldmeier, R \& Spieckermann, H 2011. God of the Living: A biblical theology. Waco: Baylor University Press. Frostin, P 1985. The hermeneutics of the poor - the 'epistemological break' in Third World Theologies. Studia Theologia 39:127-150.

Gerstenberger, E S 2002. Theologies in the Old Testament. London: T \& T Clark.

Grenz, S J 2004. Rediscovering the triune God: The trinity in contemporary theology. Minneapolis: Fortress. Gunton, C 2002. Act \& being: Towards a theology of the divine attributes. Grand Rapids: Eerdmans. Gutting, G 2011. Thinking the Impossible: French philosophy since 1960. Oxford: Oxford University Press. Henriksen, J-O 2010. Thematizing otherness: On ways of conceptualizing transcendence and God in recent philosophy of religion. Studia Theologica 64:153-176.

Hintersteiner, $\mathrm{N}$ (ed.) 2007. Naming and thinking God in Europe today: Theology in global dialogue. Amsterdam: Rodopi.

Humphreys, W L 2001. The character of God in the Book of Genesis. Louisville: Westminster John Knox. Hunt, A. 2010. The Trinity: Insights from the mystics. Collegeville: Liturgical Press.

Hurtado, L W 2010. God in the New Testament. Nashville: Abingdon.

James, I 2012. The new French philosophy. Cambridge: Polity. Jeanrond, W G \& Lande, A (eds.) 2005. The concept of God in global dialogue. Maryknoll, NY: Orbis. Jenson, R W 1995. What is the point of Trinitarian theology? in Schwöbel, C (ed.), Trinitarian theology today: Essays on divine being and act, 31-43. Edinburgh: T \& T Clark. ---2000. The hidden and Triune God. International Journal of Systematic Theology 2:5-12.

Johnson, E A 1992. SHE WHO IS: The mystery of God in feminist theological discourse. New York:

Crossroads.

---2007. Quest for the living God: Mapping frontiers in the theology of God. London: Continuum.

Kärkkäinen, V-M 2004. The doctrine of God: A global introduction. Grand Rapids: Baker.

---2009. The trajectories of the contemporary 'Trinitarian Renaissance' in different contexts. Journal of

Reformed Theology 3:7-21.

Kearney, R 2001. The God who may be: A hermeneutics of religion. Bloomington: Indiana University Press. ---2010. Anatheism: Returning to God after God. New York: Columbia University Press.

Krötke, W 2001. Gottes Klarheiten. Tübingen: Mohr Siebeck.

Lemche, N P 2008. The Old Testament between theology and history: A critical survey. Louisville: John Knox Press.

Marion, J-L, 1991. God without being. Chicago: University of Chicago Press.

McFague, S 1987. Models of God. London: SCM.

Newlands, G \& Smith, A 2010. Hospitable God: The transformative dream. Surrey: Ashgate.

Neyrey, J H 2004. Render to God: New Testament understandings of the divine. Minneapolis: Fortress.

Noll, K L 2001. The kaleidoscopic nature of divine personality in the Hebrew Bible. Biblical Interpretation 9(1):1-24.

Phan, P C (ed.) 2011. The Cambridge companion to the Trinity. Cambridge; Cambridge University Press.

Polkinghorne, J (ed.) 2010. The trinity and an entangled world: Relationality in physical science and theology. Grand Rapids: Eerdmans.

Rieger, J 2008. Resistance Spirit: The Holy Spirit and empire, in Jensen, D H (ed.), The Lord and Giver of Life: Perspectives on constructive pneumatology, 129-146. Louisville: Westminster John Knox.

Rivera, M 2007. The touch of transcendence: A postcolonial theology of God. Louisville: Westminster John Knox. 
Schwartz, R M 1997. The curse of Cain: The violent legacy of monotheism. Chicago: University of Chicago Press.

Seibert, E A 2009. Disturbing divine behavior: Troubling Old Testament images of God. Minneapolis: Fortress.

Shults, F R 2005. Reforming the doctrine of God. Grand Rapids: Eerdmans.

Smith, M S 2002. The early history of God: Yahweh and the other deities in ancient Israel. $2^{\text {nd }}$ Ed. Grand Rapids: Eerdmans.

Thompson, M M 2001. The God of the Gospel of John. Grand Rapids: Eerdmans.

Tracy, D 1994a. The return of God in contemporary theology. Concilium 1994/6:37-46.

---1994b. Theology and the many faces of postmodernity. Theology Today 51(1):104-114.

---2011. Approaching the Christian understanding of God, in Fiorenza, F S \& Galvin, J P (eds.), Systematic Theology: Roman Catholic perspectives. $2^{\text {nd }}$ ed, 109-129. Minneapolis: Fortress.

Tremlin, T 2006. Minds and gods: The cognitive foundations of religion. Oxford: Oxford University Press. Venter, R 2010. Doing Trinitarian theology: Primary references to God and imagination. In die Skriflig 44/3\&4:565-579.

Volf, M 1998. 'The Trinity is our social program': The doctrine of the Trinity and the shape of social engagement. Modern Theology 14:403-423.

Westphal, M 2004. Transcendence and self-transcendence: On God and the soul. Bloomington: Indiana University Press.

Wright, R 2009. The evolution of God: The origins of our beliefs. London: Abacus.

Woźniak, R J \& Maspero, G (eds.) 2012. Rethinking Trinitarian theology. London: T \& T Clark (Continuum).

\section{KEYWORDS}

Alterity

God

(The) Impossible

Theo-episteme

Trinitarian Renaissance

\section{TREFWOORDE}

Alteriteit

God

(Die) Onmoontlike

Teo-episteem

Trinitariese Renaissance

Prof Rian Venter

Faculty of Theology

Department of Systematic Theology

University of the Free State

P O Box 339

BLOEMFONTEIN 9300

Tel: 0722095956

E-mail: rianventer@mweb.co.za 